\title{
Strangulated adnexa due to adhesion band after hysterectomy
}

\author{
Dong Hyu Cho
}

Department of Obstetrics and Gynecology, Chonbuk National University Medical School, Jeonju, Korea

\section{Correspondence to} Professor Dong Hyu Cho, obgyn2001@jbnu.ac.kr

Accepted 11 July 2018

\section{DESCRIPTION}

A 50-year-old woman was admitted to our hospital with a 2-day history of cramping pain of the lower abdomen. She also reported an episode of nausea and vomiting prior to admission. The patient had undergone total abdominal hysterectomy for uterine myoma. Her blood pressure was $100 / 60 \mathrm{~mm} \mathrm{Hg}$, pulse rate of 70 beats/min and axillary temperature of $36.5^{\circ} \mathrm{C}$. The patient had mild direct tenderness of the lower abdomen, especially at the right lower quadrant, with no rebound tenderness or muscular guarding. Laboratory data showed a white cell count of $10100 / \mathrm{mm}^{3}$ (normal limit of 4000-10 000/ $\mathrm{mm}^{3}$ ) and a $\mathrm{C}$ reactive protein concentration of $17.25 \mathrm{mg} / \mathrm{L}$ (normal limit of $0-10 \mathrm{mg} / \mathrm{L}$ ). A plain chest X-ray revealed no free air under diaphragm. Pelvic ultrasound demonstrated smooth bilocular cystic tumour within the right adnexa that has no colour flow on Doppler.

Contrast-enhanced abdominal CT showed a hypodense area measuring $4 \times 3 \times 3 \mathrm{~cm}$ in the region of right adnexa and a band-like structure (figure 1).

Under general anaesthesia, emergency laparoscopy was performed. The laparoscopic findings revealed a $4 \times 3 \times 3 \mathrm{~cm}$ dark, haemorrhagic, edematous and strangulated right adnexa with adhesion band (figure 2). After removal of the adhesion band, the pedicle of the ovary and the tube were carefully examined. No improved colour or oedema was observed. The right adnexectomy was performed. Histological examination of the surgical specimen confirmed haemorrhagic infarction. The patient made an uneventful postoperative recovery and was discharged home on the third postoperative day.

Pelvic adhesion is a condition in which different tissues or organs are bound with fibrotic tissues in the pelvis. The incidence rate of adhesion varied from $\geq 90 \%$ in laparotomy to $55 \%-100 \%$ with common pelvic surgery. ${ }^{1}$ The severity of adhesion
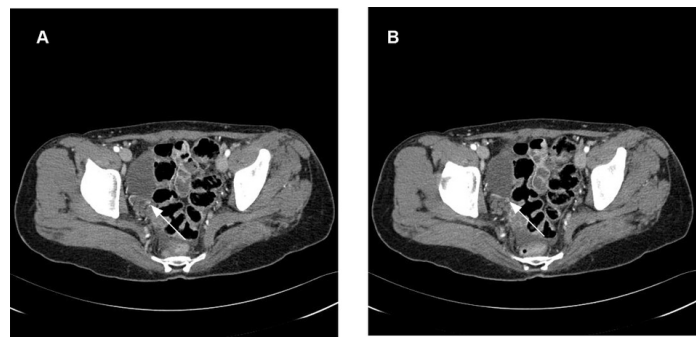

Figure 1 Strangulated adnexa due to an adhesive band in a 50-year-old woman (A). (B) Contrast-enhanced axial CT shows an adhesive band and a $4 \times 3 \times 3 \mathrm{~cm}$ hypodense right adnexal structure and an adhesive band, which represents a dilated adnexa in the right ovarian fossa.
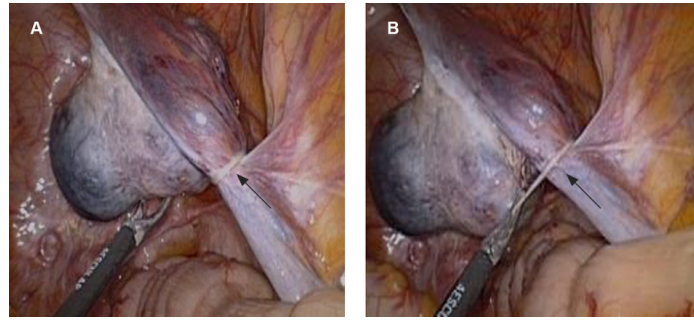

Figure 2 Laparoscopic aspects of the $4 \mathrm{~cm}$ dark haemorrhagic oedematous right adnexa with an adhesive band.

varied individually involving either two tissues bound with a very thin band-like film or a slightly partial band, while others may present with a tendon-like band that was thicker than a finger resulting in serious complications.

Strangulation due to adhesion band presents similar symptoms including severe pain of the abdomen, pelvis and lower back. Such pain may radiate to the lateral abdomen or the inguinal region. It is difficult to predict strangulation of appendages preoperatively.

In case of this study, the patient was an aerobics instructor, and the trapping of uterine adnexa by adhesion band was attributed to excessive physical exercise. It results in a gradual onset of abnormal flow of venous and lymphatic blood causing necrosis of uterine adnexa by strangulation due to increased size of uterine adnexa.

Problems of adhesion have been underestimated in current clinical practices, and most cases were detected by other practitioners several years after the original surgery. ${ }^{2}$ Clinical prevention of adhesion warrants careful haemostasis, gentle tissue handling, precise removal of necrotic tissue, minimisation of ischaemia, surgery to reduce infection and use of response-free suture materials.

\section{Learning points}

- Strangulated adnexa due to an adhesion band represent an extremely rare gynaecological emergency in women with a history of total hysterectomy presenting with acute abdominal pain.

- Early operative intervention preferably via laparoscopy is warranted to preserve ovarian function.

- Clinical prevention of adhesion requires careful haemostasis, gentle tissue handling, precise removal of necrotic tissue, minimisation of ischaemia, surgery to reduce the infection and use of response-free suture materials. 
Contributors I participated sufficiently in the work, including preparation of manuscript, and agreed to accept equal responsibility for the accuracy of the contents of the paper.

Funding The author has not declared a specific grant for this research from any funding agency in the public, commercial or not-for-profit sectors.

Competing interests None declared.

Patient consent Obtained.
Provenance and peer review Not commissioned; externally peer reviewed.

\section{REFERENCES}

1 Liakakos T, Thomakos N, Fine PM, et al. Peritoneal adhesions: etiology, pathophysiology, and clinical significance. Recent advances in prevention and management. Dig Surg 2001;18:260-73.

2 DeWilde RL, Trew G. Postoperative abdominal adhesions and their prevention in gynaecological surgery. Expert consensus position. Gynecol Surg 2007;4:161-8.

Copyright 2018 BMJ Publishing Group. All rights reserved. For permission to reuse any of this content visit

http://group.bmj.com/group/rights-licensing/permissions.

BMJ Case Report Fellows may re-use this article for personal use and teaching without any further permission.

Become a Fellow of BMJ Case Reports today and you can:

- Submit as many cases as you like

Enjoy fast sympathetic peer review and rapid publication of accepted articles

- Access all the published articles

Re-use any of the published material for personal use and teaching without further permission

For information on Institutional Fellowships contact consortiasales@bmjgroup.com

Visit casereports.bmj.com for more articles like this and to become a Fellow 